stances where science would prove itself useful on service, he explained how particulars of the enemy's guns could be deduced from fragments of the wall of a shell and photographic pictures. From a fragment they could determine whether a shell came from one of the 42-centimetre howitzers, the very existence of which still appeared in doubt. Dealing with the calculations for ascertaining how far men should stand from a gun to avoid the danger of permanent deafness, he said they need not fear to stand 12 yards behind the 42-centimetre howitzer; and so the story was discounted of the firing party taking cover roo to 200 metres away when this howitzer was fired. An application of the theory of the conduction of heat would have reassured our men that life in the trenches would not be too cold, or would at least be warmer than in the frost above, provided only the floor could be drained dry under foot. It had also to be borne in mind that the trench gave better cover than a tent.

Five years ago he had an invitation to Berlin, to visit the Military Technical Academy there. It was a magnificent institution such as we could not afford, so our rulers assured us. Prof. Cranz showed how in his department no money was spared in recent equipment, including a bomb-proof range available for artillery fire and yet in the heart of a big city. There were plenty of outdoor artillery ranges also to visit, where instructive work was in progress. The Perry system of education was adopted in Berlin. After a lecture on wireless telegraphy, the class was set to work, as he saw, in making the antennæ which had played such an important part in the war. Sixty officers were under instruction at a time for a course of three years, and he was assured their zeal was admirable. It was considered such bad form not to give the best in return for the honour and glory of the Fatherland. But our Regular was apathetic by comparison. We must put our trust in the junior ranks to push old Apathy from his stool and carry us through this war. It was a mournful contrast to revert to Woolwich. There they had been evicted and were told to found a new artillery college with the choice of a cellar under some stables or a kitchen and scullery and bare walls in a deserted hospital, there to organise victory and at no expense. With the courage of an Austrian general compelled to maintain his muzzle-loading musket a match for the Prussian needle-gun, the Military Director assured them that there was nothing superior to be found at Greenwich, in the Naval College there lodged in the old Palace. Such dismal, penurious surroundings had a disastrous effect on the genius loci, and they never really recovered from a downhearted spirit not calculated for victory. Our military science was under the rule of Thumb, the official genius. His fumbling method was considered a match for disciplined theory.

We saw already how the cost had been well laid out in this war of the Berlin Military Technical Academy, the German jumping off with a lead he was able to keep so far. The finished article of the academy was employed in the dissemination of true theory and in the scientific direction of warlike preparation as at Krupps. Assuming everything for the best for the Allies, and if we lived to go in again at Antwerp, an interesting match would be watched between our artillery science and the German, to see how long it would take us to get the other side out, compared with our own innings and the time we kept our wicket up. No long-range fire, he had been assured, was ever going to be of any use again, involving theoretical calculation. The word was "Gallop up close, to 400 yards, and let them have it."

The country was furious at the way our poor fellows were pounded mercilessly at the start by long-range accurate howitzer fire with no protection from our NO. 2360 , VOI. 94] own side. King George's stirring appeal, "Wake up, England," was intercepted by our rulers, and it was England the Unready again when our Senior Lethargy bumped into the Titanic Energy of the German Empire.

\section{SOME ASPECTS OF PROGRESS IN MODERN ZOOLOGY.1}

$\mathrm{T} T$ is our privilege to live in a time of almost unexampled progress in natural science, a time distinguished alike by discoveries of the first magnitude and by far-reaching changes in method and in point of view. The advances of recent years have revolutionised our conceptions of the structure of matter, and have seriously raised the question of the transmutation of the chemical elements. They have continually extended the proofs of organic evolution, but have at the same time opened wide the door to a re-examination of its conditions, its causes, and its essential nature. Such has been the swiftness of these advances that some effort is still required to realise what remarkable new horizons of discovery they have brought into view. A few years ago the possibility of investigating by direct experiment the internal structure of atoms, or the topographical grouping of hereditary units in the germ-cells, would have seemed a wild dream. To-day these questions stand among the substantial realities of scientific inquiry. And lest we should lose our heads amid advances so sweeping, the principles that guide scientific research have been subjected as never before to critical examination. We have become more circumspect in our attitude towards natural "laws.' We have attained to a clearer view of our working hypotheses-of their uses and their limitations. With the best of intentions we do not always succeed in keeping them clear of metaphysics, but at least we have learned to try. We perceive more and more clearly that science does not deal with ultimate problems or with final solutions. In order to live science must move. She attempts no more than to win successive points of vantage which may serve, one after another, as stepping stones to furcher progress. When these have played their part they are often left behind as the general advance proceeds.

In respect to the practical applications of science we have almost ceased to wonder at incredible prodigies of achievement; yet in some directions they retain a hold on our imagination that daily familiarity cannot shake. Not in our time, at least, will the magnificent conquests of sanitary science and experimental medicine sink to the level of the commonplace. Science here renders her most direct and personal service to human welfare; and here in less direct ways she plays a part in the advance of our civilisation that would have been inconceivable to our fathers. Popular writers delight to portray the naturalist as a kind of reanimated antediluvian, wandering aimlessly in a modern world where he plays the part of a harmless visionary; but what master of romance would have had the ingenuity to put into the head of his mythical naturalist a dream that the construction of the Panama Canal would turn upon our acquaintance with the natural history of the mosquito, or that the health and happiness of nationsnay, their advance in science, letters, and the artsmight depend measurably on the cultivation of our intimacy with the family lives of house-flies, fleas, and creatures of still more dubious antecedents!

1 Presidential address delivered to the American Association for the Advancement of Science, Philadelphia, December 28, 19r4, by Prof. E. B. Wilson. 
I.

Fourteen years ago to-night it was my privilege to deliver an address before the American Society of Naturalists, entitled "Aims and Methods of Study in Natural History," 2 in which I indicated certain important changes that were then rapidly gathering headway in zoology. To-night I once more ask attention to this subject as viewed in the fuller light of the remarkable period of progress through which biology has since been passing. I will not try to range over the whole vast field of zoology or to catalogue its specific advances. I will only permit myself a few rather desultory reflections suggested by a retrospect upon the progress of the past twenty-five years. If my view is not fully rounded, if it is coloured by a long-standing habit of looking at biological phenomena through the eyes of an embryologist, I will make no apology for what I am not able to avoid. Let me remind you also at how many points the boundaries between this and other branches of biology have become obliterated. The traditional separation between zoology and botany, for instance, has lost all significance for such subjects as genetics or cytology. Again, the artificial boundary often set up between zoology and animal physiology has wholly disappeared, owing to the extension of experimental methods to morphology and of comparative methods to physiology. I trust therefore that our brethren in botany and physiology-perhaps I should include also those in psychology-will not take it amiss if I include them with us under the good, old-fashioned name of naturalists.

The sum and substance of biological inquiry may be embodied in two questions: What is the living organism, and how has it come to be? We often find it convenient to lay the emphasis on one or the other of these questions, but fundamentally they are inseparable. The existing animal bears the indelible impress of its past; the extinct animal can be comprehended only in the light of the present. For instance, the palæontologist is most directly concerned with problems of the past, but at every step he is confronted by phenomena only to be comprehended through the study of organisms as they now are. Our main causal analysis of evolution must be carried out by experimental studies on existing forms. All this seems self-evident, yet the singular fact is that only in more recent years have students of evolution taken its truth fully to heart. And here lies the key to the modern movement in zoology of which I propose to speak.

I do not wish to dwell on matters of ancient history; but permit me a word concerning the conditions under which this movement first began to take definite shape as the nineteenth century drew towards its close. In the first three decades after the "Origin of Species" studies upon existing animals were largely dominated by efforts to reconstruct their history in the past. Many of us will recall with what ardour naturalists of the time threw themselves into this profoundly interesting task. Many of us afterwards turned to work of widely different type; but have our later interests, I wonder, been keener or more spontaneous than those awakened by the morphologicalhistorical problems, some of them already half forgotten, which we then so eagerly tried to follow? I am disposed to doubt it. The enthusiasm of youth? No doubt; but something more, too. Efforts to solve those problems have in the past often failed; they no longer occupy a place of dominating importance; but they will continue so long as biology endures, because they are the offspring of an ineradicable historical instinct, and their achievement stands secure

$$
2 \text { Science, N. S., xiii., No. 314, January 4, rgor. }
$$

No. 2360 , VOL. 94$]$ in the great body of solid fact which they have built into the framework of our science. Says Poincaré : "The advance of science is not comparable to the changes of a city, where old edifices are pitilessly torn down to give place to new, but to the continuous evolution of zoologic types which develop ceaselessly and end by becoming unrecognisable to the common sight, but where an expert eye finds always traces of the prior work of the centuries past. One must not think then that the old-fashioned theories have been sterile and vain."

After all, science impresses us by something more than the cold light of her latest facts and formulas. The drama of progress, whether displayed in the evolution of living things or in man's age-long struggle to comprehend the world of which he is a product, stirs the imagination by a warmer appeal. Without it we should miss something that we fain would keep-something, one may suspect, that has played an important part of the higher levels of scientific achievement

I seem to have been caught unawares in the act of moralising. If so, let it charitably be set down as an attempt to soften the hard fact that thirty years after the "Origin of Species" we found ourselves growing discontented with the existing methods and results of phylogenetic inquiry and with current explanations of evolution and adaptation. Almost as if by a preconcerted plan, naturalists began to turn aside from historical problems in order to learn more of organisms as they now are. They began to ask themselves whether they had not been over-emphasising the problems of evolution at the cost of those presented by life-processes everywhere before our eyes to-day. They awoke to the insufficiency of their traditional methods of observation and comparison and they turned more and more to the method by which all the great conquests of physico-chemical science had been achieved, that which undertakes the analysis of phenomena by deliberate control of the conditions under which they take place-the method of experiment. Its steadily increasing importance is the most salient feature of the new zoology.

Experimental work in zoology is as old as zoology itself; nevertheless, the main movement in this direction belongs to the past two decades. I will make no attempt to trace its development; but let me try to suggest somewhat of its character and consequences by a few outlines of what took place in embryology.

The development of the egg has always cast a peculiar spell on the scientific imagination. As we follow it hour by hour in the living object we witness a spectacular exhibition that seems to bring us very close to the secrets of animal life. It awakens an irrepressible desire to look below the surface of the phenomena, to penetrate the mystery of development. The singular fact, nevertheless, is that during the phylogenetic period of embryological research this great problem, though always before our eyes, seemed almost to be forgotten in our pre-occupation with purely historical questions-such as the origin of vertebrates or of annelids, the homologies of germ-layers, gill-slits or nephridia, and a hundred others of the same type. Now, these questions are, and always will, remain of great interest; but embryology, as at last we came to see, is but indirectly connected with historical problems of this type. The embryologist seeks first of all to attain to some understanding of development. It was therefore a notable event when, in the later 'eighties, a small group of embryologists, headed by Wilhelm Roux, turned away from the historical aspects of embryology and addressed themselves to experiments designed solely to throw light upon the mechanism of development. The full significance 
of this step first came home to us in the early 'nineties with Driesch's memorable discovery that by a simple mechanical operation we can at will cause one egg to produce two, or even more than two, perfect embryos. I will not pause to inquire why this result should have seemed so revolutionary. It was as if the scales had fallen from our eyes. With almost a feeling of shock we took the measure of our ignorance and saw the whole problem of development reopened.

The immediate and most important result of this was to stimulate a great number of important objective investigations in embryology. But let me pause for a moment to point out that at nearly the same time a similar reawakening of interest in the experimental investigation of problems of the present became evident in many other directions-for example, in studies on growth and regeneration; on cytology and protozoology; on economic biology; on ecology, the behaviour of animals and their reactions to stimuli; on heredity, variation, and selection. The leaven was indeed at work in almost every. field of zoology, and everywhere led to like results. It was a day of rapid obliteration of conventional boundary lines; of revolt from speculative systems towards the concrete and empirical methods of the laboratory; of general and far-reaching extension of experimental methods in our science.

But I will return to embryology. It may be doubted whether any period in the long history of this science has been more productive of varied and important discoveries than that which followed upon its adoption of experimental methods. In one direction the embryologist went forward to investigations that brought him into intimate relations with the physicist, the chemist, the pathologist, and even the surgeon. A flood of light was thrown on the phenomena of development by studies on differentiation, regeneration, transplantation, and grafting; on the development of isolated blastomeres and of egg-fragments; on the symmetry and polarity of the egg; on the relations of development to mechanical, physical, and chemical conditions in the environment; on isolated living cells and tissues, cultivated like micro-organisms, outside the body in vitro; on fertilisation, artificial parthenogenesis, and the chemical physiology of development. In respect to the extension of our real knowledge these advances constitute an epoch-making gain to biological science. And yet these same researches afford a most interesting demonstration of how the remoter problems of science, like distant mountain-peaks, seem to recede before us even while our actual knowledge is rapidly advancing. Thirty years after Roux's pioneer researches we find ourselves constrained to admit that in spite of all that we have learned of development the egg has not yet yielded up its inmost secrets. I have referred to the admirable discovery of Driesch concerning the artificial production of twins. That brilliant leader of embryological research had in earlier years sought for an understanding of development along the lines of the mechanistic or physico-chemical analysis, assuming the egg to be essentially a physicochemical machine. He now admitted his failure and, becoming at last convinced that the quest had from the first been hopeless, threw all his energies into an attempt to resuscitate the half-extinct doctrines of vitalism and to found a new philosophy of the organism. Thus the embryologist, starting from a simple laboratory experiment, strayed further and further from his native land until he found himself at last quite outside the pale of science. He did not always return. Instead, he sometimes made himself a new home-upon occasion even established himself in the honoured occupancy of a university chair of philosophy!

No. 2360 , voL. 94$]$
The theme that is here suggested tempts me to a digression, because of the clear light in which it displays the attitude of modern biology towards the study of living things. It is impossible not to admire the keenness of analysis, and often the artistic refinement of skill (which so captivates us, for instance, in the work of M. Bergson) with which the neo-vitalistic writers have set forth their views. For my part, I am ready to go further, admitting freely that the position of these writers may at bottom be well grounded. At any rate, it is well for us now and then to be rudely shaken out of the ruts of our accustomed modes of thought by a challenge that forces upon us the question whether we really expect our scalpels and microscopes, our salt-solutions, formulas, and tables of statistics, to tell the whole story of living things. It is, of course, impossible for us to assert that they will. And yet the more we ponder the question the stronger grows our conviction that the "entelechies" and such-like agencies conjured forth by modern vitalism are as sterile for science as the final causes of an earlier philosophy; so that Bacon might have said of the former, as he did of the latter, that they are like the Vestal virgins-dedicated to God, and barren. We must not deal too severely with the naturalist who now and then permits himself an hour of dalliance with them. An uneasy conscience will sooner or later drive him back into his own straight and narrow way with the insistent query: The specific vital agents, sui generis, that are postulated by the vitalist-are they sober realities? Can the existence of an "élan vital," of "entelechies," of "psychoids," be experimentally verified? Even if beyond the reach of verification may they still be of practical use in our investigations on living things, or find their justification on larger grounds of scientific expediency. However philosophy may answer, science can find but one reply. The scientific method is the mechanistic method. The moment we swerve from it by a single step we set foot in a foreign land where a different idiom from ours is spoken. We have, it is true, no proof whatever of its final validity. We do not adopt the mechanistic view of organic nature as a dogma but only as a practical programme of work, neither more nor less. We know full well that our present mechanistic conceptions of animals and plants have not yet made any approach to a complete solution of the problems of life, whether past or present. This should encourage us to fresh efforts, for just in the present inadequacy of these conceptions lies the assurance of our future progress. But the way of unverifiable (and irrefutable) imaginative constructions is not our way. We must hold fast to the method by which all the great advances in our knowledge of nature have been achieved. We shall make lasting progress only by plodding along the old, hard beaten trail blazed by our scientific fathers-the way of observation, comparison, experiment, analysis, synthesis, prediction, verification. If this seems a prosaic programme we may learn otherwise from great discoverers in every field of science who have demonstrated how free is the play that it gives to the constructive imagination and even to the faculty of artistic creation.

\section{II.}

Thus far I have desired to emphasise especially the reawakening of our interest in problems of the present, and the growing importance of experimental methods in our science. It is interesting to observe how these changes have affected our attitude towards the historical problem as displayed in the modern study of genetics. Even here we are struck by the same shifting of the centre of gravity that has been remarked in other fields of inquiry. In the Darwinian era 
studies on variation and heredity seemed significant mainly as a means of approach to the problems of evolution. The post-Darwinians awoke once more to the profound interest that lies in the genetic composition and capacities of living things as they now are. They turned aside from general theories of evolution and their deductive application to special problems of descent in order to take up objective experiments on variation and heredity for their own sake. This was not due to any doubts concerning the reality of evolution or to any lack of interest in its problems. It was a policy of masterly inactivity deliberately adopted; for further discussion concerning the causes of evolution had clearly become futile until a more adequate and critical view of existing genetic phenomena had been gained. Investigators in genetics here followed precisely the same impulse that had actuated the embryologists; and they, too, reaped a rich harvest of new discoveries. Foremost among them stands the re-discovery "of Mendel's long-forgotten law of heredity-a biological achievement of the first rank which in the year Igoo suddenly illuminated the obscurity in which students of heredity had been groping. Another towering landmark of progress is De Vries's great work on the mutation theory, published a year later, which marked almost as great a transformation in our views of variation and displayed the whole evolution problem in a new light. In the era that followed, the study of heredity quiclily became not only an experimental, but almost an exact science, fairly comparable to chemistry in its systematic employment of qualitative and quantitative analysis, synthesis, prediction, and verification. More and more clearly it became evident that the phenomena of heredity are manifestations of definite mechanism in the living body. Microscopical studies on the germ-cells made known an important part of this mechanism and provided us with a simple mechanical explanation of Mendel's law. And suddenly, in the midst of all this, by a kaleidoscopic turn, the fundamental problem of organic evolution crystallises before our eyes into a new form that seems to turn all our previous conceptions topsy-turvy.

I will comment briefly on this latest view of evolution, partly because of its inherent interest, but also because it again exemplifies, as in the case of embryology, that temptation to wander off into metaphysics (sit venia verbo!) which seems so often to be engendered by new and telling discoveries in science. The fundamental question which it raises shows an interesting analogy to that encountered in the study of embryology, and may conveniently be approached from this side.

To judge by its external aspects, individual employment, like evolution, would seem to proceed from the simple to the complex; but is this true when we consider its inner or essential nature? The egg appears to the eye far simpler than the adult; yet genetic experiment seems continually to accumulate evidence that for each independent hereditary trait of the adult the egg contains a corresponding something (we know not what) that grows, divides, and is transmitted by cell-division without loss of its specific character and independently of other somethings of like order. Thus arises what I will call the puzzle of the microcosm. Is the appearance of simplicity in the egg illusory? Is the hen's egg fundamentally as complex as the hen, and is development merely the transformation of one kind of complexity into another? Such is the ultimate question of ontogeny, which in one form or another has been debated by embryologists for more than two centuries. We still cannot answer it. If we attempt to do so, each replies according to the dictates of his individual temperament-that is to say, he resorts to some kind of symbolism; and he still remains free to choose that particular form which he finds most convenient, provided it does not stand in the way of practical efforts to advance our real knowledge through observation and experiment. Those who must have everything reduced to hard and fast formulas will no doubt find this rather disconcert. ing; but worse is to follow. Genetic research now confronts us with essentially the same question as applied to the evolutionary germ. The puzzle of the microcosm has become that of the macrocosm. Were the primitive forms of life really simpler than their apparently more complex descendants? Has organic evolution been from the simple to the complex, or only from one kind of complexity to another? May it even have been from the complex to the simple by successive losses of inhibiting factors which, as they disappear, set free qualities previously held in check? The last of these is the startling question that the president of the British Association propounds in his recent brilliant address at Melbourne, asking us seriously to open our minds to the inquiry: "Whether evolution can at all reasonably be represented as an unpacking of an original complex which contained within itself the whole range of complexity which living things exhibit?" This conception, manifestly, is nearly akin to the theory of pangenesis and individual development, as elaborated especially by $D e$ Vries and by Weismann. It inevitably recalls also, if less directly, Bonnet's vision of "palingenesis," whirh dates from the eighteenth century.

We should be grateful to those who help us to open our minds; and Prof. Bateson, as is his wont, performs this difficult operation in so large and masterly a fashion as to command our lively admiration. It must be said of his picturesque and vigorous discussion that we are kept guessing how far we are expected to take it seriously, or at least literally. We have always a lurking suspicion that possibly his main purpose may, after all, be to remind us, by an objectlesson, how far we still are from comprehending the nature and causes of evolution, and this suspicion is strengthened by the explicit statement in a subsequent address, delivered at Sydney, that our knowledge of the nature of life is "altogether too slender to warrant speculation on these fundamental questions." Let us, however, assume that we are seriously asked to go further and to enter the cul de sac that Prof. Bateson so invitingly places in our way. Once within it, evidently we are stalemated in respect to the origin and early history of life; but as to that, one form of total ignorance is perhaps as good as another, and we can still work out how the game has been played, even though we can never find out how the pieces were set up. But has the day so soon arrived when we must resign ourselves to such an ending? Are we prepared to stake so much upon the correctness of a single hypothesis of allelomorphism and dominance? This hypothesis-that of "presence and absence "- has undoubtedly been a potent instrument of investigation; but there are some competent students of genetics who seem to find it equally simple to formulate and analyse the phenomena by the use of a quite different hypothesis, and one that involves no such paradoxical consequences in respect to the nature of evolution. Are we not then invited to strain at a gnat and to swallow a camel?

But I pass over the technical basis of the conception in order to look more broadly at its theoretic superstructure. Is not this, once again, a kind of symbolism by which the endeavour is made to deal with a problem that is for the present out of our reach? Neither you nor I, I dare say, will hesitate to maintain that the primordial Amoba, if we may so dub the

NO: 2260 . VOL. 94$]$ 
earliest of our ancestors) embodied in some sense or other all the potentialities, for better or for worse, that are realised before us at this moment in the American Association for the Advancement of Science. But if we ask ourselves exactly what we mean by this we discover our total inability to answer in more intelligible terms. We cannot, it is true, even if we would, conquer the temptation now and then to spread the wings of our imagination in the thin atmosphere of these upper regions; and this is no doubt an excellent tonic for the cerebrum provided we cherish no illusions as to what we are about. No embryologist, for example, can help puzzling over what I have called the problem of the microcosm; but he should be perfectly well aware that in striving to picture to his imagination the ultimate organisation of the egg, of the embryological germ, that is actually in his hands for observation and experiment, he is perilously near to the habitat of the mystic and the transcendentalist. The student of evolution is far over the frontier of that forbidden land, in any present attack upon the corresponding problem of the macrocosm; for the primordial Amœba, the evolutionary germ, is inconceivably far out of our reach, hidden behind the veil of a past the beginnings of which lie wholly beyond our ken. And why, after all, should we as yet attempt the exploration of a region which still remains so barren and remote? Surely not for the lack of accessible fields of genetic research that are fertile and varied enough to reward our best efforts, as no one has more forcibly urged or more brilliantly demonstrated by his own example than Prof. Bateson himself.

Perhaps it would be the part of discretion to go no further. But the remarkable questions that Prof. Bateson has raised concerning the nature of evolution leave almost untouched the equally momentous problem as to what has guided its actual course. In approaching my close I skall be bold enough to venture a step in this direction, even one that will bring us upon the hazardous ground of organic adaptations and the theory of natural selection. I need not say that this subject is beset by intricate and baffing difficulties which have made it a veritable bone of contention among naturalists in recent years. In our attempts to meet them we have gone to some curious extremes. On the one hand, some naturalists have in effect abandoned the problem, cutting the Gordian knot with the conclusion that the power of adaptation is something given with organisation itself and as such offers a riddle that is for the present insolible. In another direction we find attempts to take the problem in flank, to restate it, to ignore itsometimes, it would almost seem to argue it out of existence. It has been urged in a recent valuable work-by an author, I hasten to say, who fully accepts both the mechanistic philosophy and the principle of selection-that fitness is a reciprocal relation, involving the environment no less than the organism. This is both a true and a suggestive thought; but does it not leave the naturalist floundering amid the same old quicksands? The historical problem with which he has to deal must be grappled at closer quarters. $\mathrm{He}$ is everywhere confronted with specific devices in the organism that must have arisen long after the conditions of environment to which they adjusted. Animals that live in water are provided with gills. Were this all we could probably muddle along with the notion that gills are no more than lucky accidents. But we encounter a sticking point in the fact that gills are so often accompanied by a variety of ingenious devices, such as reservoirs, tubes, valves, pumps, strainers, scrubbing brushes, and the like, that are obviously tributary to the main function of breathing. Given water, asks the naturalist, how has all this come into existence and been perfected? The question is an inevitable product of our common sense. The metaphysician, I think, is not he who asks but he who would suppress it.

For all that it would seem that some persons find the very word adaptation of too questionable a reputation for mention in polite scientific society. Allow me to illustrate by a leaf taken from my own notebook. I once ventured to publish a small experimental work on the movements of the fresh-water Hydra with respect to light. What was my surprise to receive a reproof from a friendly critic, because I had not been content with an objective description of the movements but had also been so indiscreet as to emphasise their evident utility to the animal. I was no doubt too young then-I fear I am too old nowto comprehend in what respect I had sinned against the light. That was long ago. I will cite a more recent example from a public discussion on adaptation that took place before the American Suciety of Naturalists a year or two since. "The dominance of the concept of adaptation," said one naturalist. "which now distinguishes our science from the nonbiological ones, is related to the comparatively youthful stage of development so far attained by biology, and not to any observed character in the living objects with which we deal." Here, we almost seem to catch an echo from the utterances of a certain sect of selfstyled "scientists" who love to please themselves with the quaint fancy that physical disease is but one of the "errors of mortal mind."

Now, it is undoubtedly true that many adaptations, to cite Prof. Bateson once more, are "not in practice a very close fit." Even the eye, as Helmholtz long ago taught us, has some defects as an optical instrument; nevertheless, it enables us to see well enough to discern some food for reflection concerning adaptations among living things. And it is my impression that efforts to explain adaptations are likely to continue for the reason that naturalists as a body, perhaps influenced by Huxlev's definition of science, have an obstinate habit of clinging to their common sense.

At the present day there is no longer the smallest doubt of the great outstanding fact that many complex structural adaptations-it would probably be correct to say all such-have not come into existence at a single stroke but have moved forward step by step to the attainment of their full degree of perfection. What has dominated the direction and final outcome of such advancing lines? We cannot yet answer this question with any degree of assurance; but procrastinate as we mav, it must in the end squarely be faced. We have seen one theory after another forced back within narrower lines or crumbling away before the adverse fire of criticism. I will not pause to recount the heavy losses that must be placed to the account of sexual selection, of neo-Lamarckism, of orthogenesis. Some naturalists, no doubt, would assign a prominent place in this list of casualties to natural selection; but probably there are none who would hold that it has been destroyed utterly. The crux lies in the degree of its efficacy. Stated as an irreducible minimum the survival of the fit is an evident fact. . Individuals that are unfitted to live, or to reproduce, leave few or no descendants-so much, at least, must be admitted by all. But does this colourless and trite conclusion end the matter or adequately place before us the significance of the facts? Just here lies the whole issue. Does destruction of the unfit accomplish no other result than to maintain the status quo, or has it conditioned the direction of progress? Accepting the second of these alternatives, Darwin went so far as to assign to it a

$$
\text { No. } 2360 \text {, VOL. 94] }
$$


leading rôle among the conditions to which the living world owes its existing configuration. Since his time the aspect of the problem has widely changed. We must rule out the question of the origin of neutral or useless traits. We must not confuse the evolution of adaptations with the origin of species. We must bear in mind the fact that Darwin often failed to distinguish between non-heritable fluctuations and hereditary mutations of small degree. We are now aware that many apparently new variations may be no more than recombination-products of pre-existing elements, We should, no doubt, make a larger allowance for the rôle of single "lucky accidents" in evolution than did many of the earlier evolutionists. And yet, so far as the essence of the principle is concerned, I am bound to make confession of my doubts whether any existing discussion of this problem affords more food for reflection, even to-day, than that contained in the sixth and seventh chapters of the "Origin of Species" and elsewhere in the works of Darwin.

Undeniably there is a large measure of truth in the contention that natural selection still belongs rather to the philosophy than to the science of biology. In spite of many important experimental and critical studies on the subject Darwin's conception still remains to-day in the main what it was in his own time, a theory, a logical construction, based, it is true, on a multitude of facts, yet still awaiting adequate experimental test. Simple though the principle is, its actual effect in nature is determined by conditions that are too intricate and operate through periods too great to be duplicated in the experimental laboratory. Hence it is that even after more than fifty years of Darwinism the time has not yet come for a true estimate of Darwin's proposed solution of the great problem.

But there is still another word to be said. Too often in the past the facile formulas of natural selection have been made use of to carry us lightly over the surface of unsuspected depths that would richly have repaid serious exploration. In a healthy reaction from this purblind course we have made it the modf to minimise Darwin's theory; and no doubt a great service has been rendered to our study of this problem by the critical and sceptical spirit of modern experimental science. But there is a homely German saying that impresses upon us the need of raution as we empty out the bath lest we pour out the child too. This suggests that we should take heed how we under-estimate the one really simple and intelligible explanation of organic adaptations that has thus far been placed in our hands. And in some minds-if I include my own among them let it be set down to that indiscretion at which I have hinted-the impression grows that our preoccupation with the problem as it appears at short focus may in some measure have dimmed our vision of larger outlines that must be viewed at longer range; that we may have emphasised minor difficulties at the cost of a larger truth. To such minds it will seem that the principle of natural selection, while it may not provide a master key to all the riddles of evolution, still looms up as one of the great contributions of modern science to our understanding of nature.

I have taken but a passing glance at a vast and many-sided subject. I have tried to suggest that the tide of speculation in our science has far receded; that experimental methods have taken their rightful place of importance; that we have attained to a truer perspective of past and present in our study of the problems of animal life. The destructive phase through which we have passed has thoroughly cleared the ground for the new constructive era on which we now have entered. All the signs of the times indicate

$$
\text { NO. } 2360 \text {, VOL. 94] }
$$

that this era will long endure. And this is of good augury for a future of productive effort, guided by the methods of physico-chemical science, impatient of merely a priori constructions, of academic discussions, of hypotheses that cannot be brought to the test of experimental verification. The work ahead will make exacting technical demands upon us. The pioneer days of zoology are past. The naturalist of the future must be thoroughly trained in the methods and results of chemistry and physics. He must prepare himself for a life of intensive research, of high specialisation; but in the future even more than in the past he will wander in vain amid the dry sands of special detail if the larger problems and general aims of his science be not held steadfastly in view. For these are the outstanding beacon lights of progress; and while science viewed at close range seems always to grow more complex, a wider vision shows that her signal discoveries are often singularly simple. This perhaps may help us to keep alive the spirit of the pioneers who led the advances of a simpler age; and it is full of hope for the future.

\section{UNIVERSITY AND EDUCATIONAL INTELLIGENCE.}

Birmingham.-The Huxley Lecture will be delivered on January 2 I by M. Emile Verhaeren (the national poet of Belgium), who has chosen as his subject "L'Esprit Belge."

London.-Among the opening lectures in the Lent Term at the Bedford College for Women are several which are open free to the public without ticket. In the department of geology a series of four lectures on minerals used as gem stones will be given on Thursdays at 5.15 p.m., beginning on January 28 , by Dr. A. Hutchinson and Dr. H. H. Thomas. In the botany department Mr. W. Neilson Jones will lecture on Mondays at 5 p.m., beginning on January 18 , on phenomena of heredity. There will also be lectures on hygiene, mathematics, physiology, and chemistry.

A cOURSE of lectures to the University of London Officers Training Corps on military subjects is being given by the members of the staff of Birkbeck College, London, on Tuesdays, at 8 p.m. The first lecture, on the economics of war, was given on January ig by the principal of the college, Dr. G. Armitage-Smith. Forthcoming lectures on succeeding Tuesdays are as follows :-_"Bacteria," Dr. H. C. I. Gwynne-Vaughan; "Some Past Fights for Freedom," Mr. L. Ricci ; "Trench Making," Dr. J. W. Evans; "Report Writing," Mr. J. H. Lobban; "International Law of War on Land," Mr. G. C. Rankin; "Map Making and Map Reading," Dr. J. F. Unstead; "Range Finding," Dr. A. Griffiths; "Explosives," Dr. G. Senter; "War Clouds of Modern Europe," Mr. A. Jones; "An Ancient Drill Book," Mr. F. A. Wright. The lectures are intended primarily for cadets of the Officers Training Corps, but are open to all persons interested, without fee.

A copy of the "General Information Number" of the Bulletin of the Armour Institute of Technology has been received from Chicago. Full particulars are given of the courses offered in mechanical, electrical, civil, chemical, and fire protection engineering, as well as those in architecture and the industrial arts. Each of these four-year courses represents a carefully balanced group system of studies, combining a thorough and broad scientific training with the elements of liberal culture, and all lead to the degree of bachelor of science. 